\title{
Osmo-Priming with Seaweed Extracts Enhances Yield of Salt-Stressed Tomato Plants
}

\author{
Emilio Di Stasio ${ }^{\dagger}$, Valerio Cirillo *, ${ }^{\star}$, Giampaolo Raimondi, Maria Giordano®, Marco Esposito \\ and Albino Maggio
}

Department of Agricultural Science, University of Napoli Federico II, Portici, 80055 Naples, Italy; emiliodistasio@gmail.com (E.D.S.); giampaolo.raimondi@unina.it (G.R.); maria.giordano@unina.it (M.G.); marco.esposito3@unina.it (M.E.); almaggio@unina.it (A.M.)

* Correspondence: valerio.cirillo@unina.it

+ These authors have contributed equally to this work.

Received: 9 September 2020; Accepted: 7 October 2020; Published: 13 October 2020

\begin{abstract}
Salinization of agricultural land is an expanding phenomenon, which requires a multi-level strategy to counteract its deleterious effects on crop yield and quality. Plant biostimulants are increasingly used in agriculture with multiple purposes, including protection against abiotic stresses such as drought and salinity. The complex nature of plant biostimulants, however, makes it difficult to establish a cause-effect relationship between the composition of the commercial product and its expected effects. Here, we demonstrate that field applications of two algal derivatives (Rygex, R and Super Fifty, SU) cause a $26 \%$ reduction in shoot biomass and a remodulation of the root-to-shoot ratio under moderately saline irrigation $\left(6.3 \mathrm{dS} \mathrm{m}^{-1}\right)$. Moreover, plants treated with the two algal derivatives showed lower leaf water potential and improved water use efficiency under control conditions, suggesting an osmo-priming effect by these two products. These pre-adaptation responses increased tomato yield by $49 \%$ (R) and 70\% (SU) regardless of the salinity level, with a remarkable reallocation of the biomass toward the fruits. Overall, our results suggest that the application of these two biostimulants can be useful in the open field to protect tomato plants from osmotic stress due to seasonal salinization, a phenomenon that typically occurs in arid and semi-arid environments.
\end{abstract}

Keywords: biostimulants; Ascophyllum nodosum; salinity; biomass partitioning

\section{Introduction}

Salinity is one of the major environmental constraints affecting crop development in arid and semi-arid regions of the world, where poor quality water is frequently used for irrigation [1]. In these areas, salinization increases at an annual rate of $10 \%$ [1,2]. The effects of salt stress on plants are variable and depend on the intensity and duration of the stress as well as the specific crop tolerance [3]. There are different approaches to cope with salinization in agriculture, including crop management to control and contain the concentration of salts in the rhizosphere [4,5], as well as plant breeding and genetic engineering to improve plant tolerance to salinity [6,7]. However, additional stress adaptation/mitigation strategies will be necessary in the future because sustainable agricultural practices will be increasingly required to improve plant adaptation to climate-associated abiotic stresses with minimal environmental impact [5,8].

Plant biostimulants are gaining an increasingly broader field of applications [8]. These are substances and/or microorganisms that enhance plant growth, increase tolerance to unfavorable environmental conditions, and improve plant resource use efficiency [9]. Several biostimulants such as protein hydrolysate, glycine betaine, bacteria, mycorrhizal fungi or algal extracts [10-12] have been successfully used for their protective effect against abiotic stresses. Among all, seaweed extracts (SWEs) 
have been proven to enhance plant growth and stress tolerance through a wide range of bioactive molecules that act as functional components in commercial products $[13,14]$. The beneficial effects of SWEs have been documented on both product yields and quality [15], alleviation of drought and temperature stress symptoms [16,17], and improved nutrient uptake [18,19]. A thorough understanding of biostimulants' mode of action on plants is needed to functionalize their use in specific environmental conditions, thus maximizing the effectiveness of their application [20]. Previous reports showed that part of the biostimulant activity of SWE was associated with a priming effect enabling plants to better cope with stress $[14,20]$. Induction of a moderate and controlled stress at seeds or plantlets level (priming) is a useful strategy for the activation of stress-protective mechanisms in plants, which may help to overcome adverse environmental conditions throughout the growing season [21-24]. Beneficial effects of priming have been assessed on seeds, where a pre-sowing osmo-priming induced higher yields and tolerance under drought stress [25]. Osmo-priming activates different mechanisms of stress tolerance (i.e., improved antioxidant capacity, activation of signaling molecules, abscisic acid production) making the plant prone to better cope with the subsequent stress, thus maximizing plants productivity performances and survival [26]. Osmo-priming may also anticipate flower setting and shorten the time to harvest so to avoid plants exposure to salt build-up in the root zone [27-29]. SWE formulations generally contain high concentrations of organic and inorganic osmolytes that, when delivered via irrigation, may be partially absorbed by the plant and/or may induce a moderate and transient osmotic stress $[13,20]$. When SWE applications are performed throughout the growing season, the continuous osmo-priming can induce morphological and physiological adaptive changes that can facilitate plant response to unexpected and/or seasonal stress [20]. In addition, SWEs contain many other beneficial molecules without specific osmotic activity which can also contribute to enhance plant growth and productivity performances and/or interact with specific stress-protective molecules with well characterized hormone-like, antioxidant, and/or defensive activity $[13,30,31]$.

Here, we report on the application of two commercial Ascophyllum nodosum algal derivative, pre-adapted tomato plants to salt stress via reshaping of biomass allocation and plant morphology - both under control and salt stress conditions. The morpho-physiological modifications induced in SWE-treated plants were associated with higher photosynthetic efficiency, which also contributed to a functional resource allocation to the reproductive and commercial part of the plant. These results indicate that osmo-priming is a physiological mechanism that should be further explored in field applications to better target and/or potentiate biostimulants activity to increase crop productivity.

\section{Materials and Methods}

\subsection{Experimental Conditions and Crop Management}

A field experiment was carried at the experimental farm of the University of Naples Federico II, southern Italy (lat. $43^{\circ} 31^{\prime} \mathrm{N}$, long. $14^{\circ} 58^{\prime} \mathrm{E}$; alt. $60 \mathrm{~m}$ above sea level) on a tomato (Solanum lycopersicum L.) crop. The experiment was performed on sub-alkaline soil ( $\mathrm{pH} 7.5$ ), silty-clay-loam (Clay $334 \mathrm{~g} \mathrm{~kg}^{-1}$, Silt $241 \mathrm{~g} \mathrm{~kg}^{-1}$, Sand $\left.425 \mathrm{~g} \mathrm{~kg}^{-1}\right)$ with low nitrogen and soil organic matter $\left(1.2 \mathrm{~g} \mathrm{~kg}^{-1}\right.$ and $18.4 \mathrm{~g} \mathrm{~kg}^{-1}$, respectively). Plots of all treatments were moldboard plowed to $30 \mathrm{~cm}$ depth followed by secondary tillage with a soil grubber and harrow for seedbed and transplanting preparation. Treatments were arranged in a randomized block design with three replications, in plots of $80 \mathrm{~m}^{2}$. Tomato seeds (Solanum lycopersicum L.) cv Vulcan F1 (Nunhems ${ }^{\circledR}$ — Bayer, Leverkusen, Germany) were germinated in peat and grown until the 3rd-4th true leaf. Plants were transplanted at 32 days after sowing (DAS) with a plant density of 3.3 plants per $\mathrm{m}^{2}$. Top-dress $\mathrm{N}$ was applied as ammonium nitrate at a rate of $80 \mathrm{~kg} \mathrm{ha}^{-1}$. Weeds were controlled mechanically. Plants were irrigated, starting from 33 DAS, with drip lines with emitters of $0.4 \mathrm{~L} \mathrm{~h}^{-1}$ flow, $0.3 \mathrm{~m}$ apart. Pre-sowing mineral fertilizer was applied with $30 \mathrm{~kg} \mathrm{ha}^{-1}$ of N, $45 \mathrm{~kg} \mathrm{ha}^{-1}$ of P and $40 \mathrm{~kg} \mathrm{ha}^{-1}$ of $\mathrm{K}$. Treatments included two levels of salinity ( 0 and $80 \mathrm{mM} \mathrm{NaCl})$ and three SWE: control (C), Rygex (R) (Agriges S.R.L., Benevento, Italy), and Super Fifty (SU) (BioAtlantis Ltd., Clash Industrial Estate, Tralee, Co. Kerry, Ireland). SWEs in 
liquid formulation were dissolved in tap water at the dose of $2.50 \mathrm{~mL} \mathrm{~L}^{-1}$ and $2.00 \mathrm{~mL} \mathrm{~L}^{-1}$ of Rygex and Super Fifty, respectively, as suggested by the producing companies. The solution obtained was pumped from independent $1000 \mathrm{~L}$ tanks and applied to the soil through the drip irrigation system. The SWE treatments were performed every 15 days, starting at transplanting. The salinity treatment started from $37 \mathrm{DAS}$, by adding $80 \mathrm{mM} \mathrm{NaCl}$ in tap water, from independent $1000 \mathrm{~L}$ tanks connected to the drip irrigation system. Salt was applied weekly until the end of the experiment.

\subsection{Soil Salinity}

Soil salinity was assessed by measuring the electrical conductivity (EC) on a soil extract of five samples for each plot. Soil samples were collected in each plot at $0.3 \mathrm{~m}$ depth increments along the 0-1.2 $\mathrm{m}$ soil profile. Soil samples were dried in an oven at $60^{\circ} \mathrm{C}$ for $72 \mathrm{~h}$ and then sieved $(2 \mathrm{~mm})$. A 1:5 soil/water suspension was agitated for $2 \mathrm{~h}$ and then centrifuged. The EC of the extract was measured with a conductivity meter (EC meter Basic 30, Crison, Alella, Barcelona, Spain). Soil samples were collected $24 \mathrm{~h}$ after the first saline irrigation. The EC of the salinized plots was $6.3 \mathrm{dS} \mathrm{m}^{-1}$ whereas the EC of non-salinized control was $0.5 \mathrm{dS} \mathrm{m}^{-1}$.

\subsection{Growth and Yield Measurements}

At harvest (115 DAS), tomato plants were separated into shoot, roots, and fruits for the fresh biomass determination, and their tissues were dried to constant weight in a forced-air oven at $80^{\circ} \mathrm{C}$ for $72 \mathrm{~h}$ for dry biomass (DW) determination. Leaf area measurements were performed with a leaf area meter (LI-3100C, LICOR). The number of fruits per plant and their average weight was reported. Root to shoot ratio (R/S) and harvest index (fruit biomass as a proportion of total biomass) were calculated on dry biomass basis. Firmness was evaluated with a bench penetrometer.

\subsection{Physiological Parameters}

Net photosynthesis and the stomatal conductance were measured on a fully expanded leaf with a gas exchange system (HCM 1000, Walz, Effeltrich, Germany). Measurements were carried out at 80 DAS. Intrinsic water use efficiency (iWUE) was calculated as the ratio between the net assimilation rate (Pn) and the stomatal conductance (gs). Leaf water potential was measured at 80 DAS using a dewpoint psychrometer (WP4, Decagon Devices, Pullman, WA, USA) on samples of fully expanded leaves.

\subsection{Mineral Analysis}

The mineral composition was detected on dried, finely ground (mesh $0.5 \mathrm{~mm}$ ) samples of tissues. Anions and cations were extracted in Milli-Q water (Merck Millipore, Darmstadt, Germany) in a thermostatic bath at $80^{\circ} \mathrm{C}$ for $10 \mathrm{~min}$ (ShakeTemp SW22, Julabo, Seelbach, Germany). After centrifuging at $6000 \mathrm{rpm}$ for $10 \mathrm{~min}$, the supernatant was filtered $(0.2 \mu \mathrm{m})$ and analyzed by ion chromatography with suppressed conductivity detection using a Dionex ICS-3000 system (Sunnyvale, CA, USA). Cations analysis was carried out with the isocratic method $(20 \mathrm{mM}$; flow rate $1 \mathrm{~mL} / \mathrm{min})$ using an IonPac CS12A column with a CG12A guard column and methanesulfonic acid as eluent. Anions analysis was performed with $\mathrm{NaOH}$ gradient $(1 \mathrm{mM}-50 \mathrm{mM}$; flow rate $1.5 \mathrm{~mL} / \mathrm{min})$ using an IonPac AS11HC column with an AG11HC guard column.

\subsection{Statistical Analysis}

Data were analyzed by ANOVA and Duncan multiple comparison tests were used to determine differences between means $(p \leq 0.05)$. 


\section{Results}

\subsection{Biomass Components}

Shoot fresh weight was significantly reduced by the separate effect of biostimulant and salinity treatments. Both Rygex and Super Fifty reduced shoot fresh weight (FW) by $18 \%$ and 20\%, respectively (Table 1). The salt treatment reduced shoot fresh weight by $26 \%$ (Table 1 ). SWE treatments significantly increased the root to shoot ratio (R/S) (+57\% for Rygex; $30 \%$ for Super Fifty) compared to control plants (Table 1), while the single effect of salinity did not affect this parameter (Table 1). Shoot fresh weight and $R / S$ ratio were not affected by the interaction between biostimulant treatment and salinity (Table 1).

Table 1. Shoot and root biomass components in control plants and plants treated with Rygex and Super Fifty and subjected to $0 \mathrm{mM} \mathrm{NaCl}$ (S0) and $80 \mathrm{mM} \mathrm{NaCl}$ (S80). Asterisks indicate significant differences according to ANOVA (ns = not significant; ${ }^{*}=p<0.05 ;{ }^{* *}=p<0.01 ;{ }^{* * *}=p<0.001$ ). For statistically significant differences induced by one of the two factors, different letters indicate significant differences according to Duncan post-hoc test $(p<0.05)$.

\begin{tabular}{ccccc}
\hline & Shoot FW & R/S & Leaf Area & Root DW \\
\hline & $\mathbf{g}$ & & $\mathbf{c m}^{\mathbf{2}}$ & $\mathbf{g}$ \\
\hline Biostimulant (B) & & & & \\
Control & $877.1 \mathrm{a}$ & $0.08 \mathrm{~b}$ & $6821 \mathrm{a}$ & $8.99 \mathrm{~b}$ \\
Rygex & $718.7 \mathrm{~b}$ & $0.11 \mathrm{a}$ & $6663 \mathrm{a}$ & $15.1 \mathrm{a}$ \\
Super Fifty & $693.2 \mathrm{~b}$ & $0.13 \mathrm{a}$ & $5897 \mathrm{~b}$ & $12.7 \mathrm{a}$ \\
Salinity (S) & & & & \\
S0 & $879.6 \mathrm{a}$ & 0.11 & $7918 \mathrm{a}$ & $13.11 \mathrm{a}$ \\
S80 & $646.4 \mathrm{~b}$ & 0.11 & $5002 \mathrm{~b}$ & $11.46 \mathrm{~b}$ \\
Significance & & & & $* *$ \\
B & $* * *$ & $* *$ & $*$ & $*$ \\
S & $* * *$ & $\mathrm{~ns}$ & $* * *$ & $*$ \\
BxS & $\mathrm{ns}$ & $\mathrm{ns}$ & $*$ & \\
\hline
\end{tabular}

Leaf area and root dry weight were significantly affected by the interaction between biostimulant treatments and salinity (Table 1). Plants growing in the absence of stress had similar leaf area (Figure 1A), whereas SWE-treated plants had a significant reduction in leaf area (-35\% with Super Fifty; $-15 \%$ with Rygex) compared to control plants in response to salinization (Figure 1A). With respect to root dry weight, Rygex and Super Fifty induced a similar increase in this parameter under optimal condition ( $+58 \%$ compared to the control). However, only Rygex was able to induce such an increase under salinity (+78\%) (Figure 1B).

A

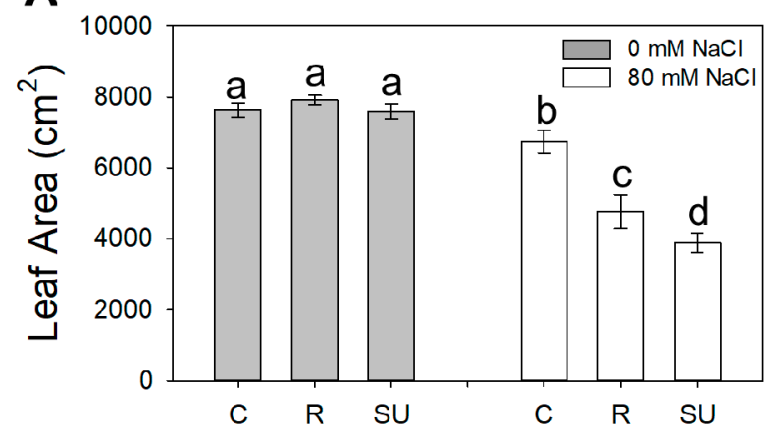

B

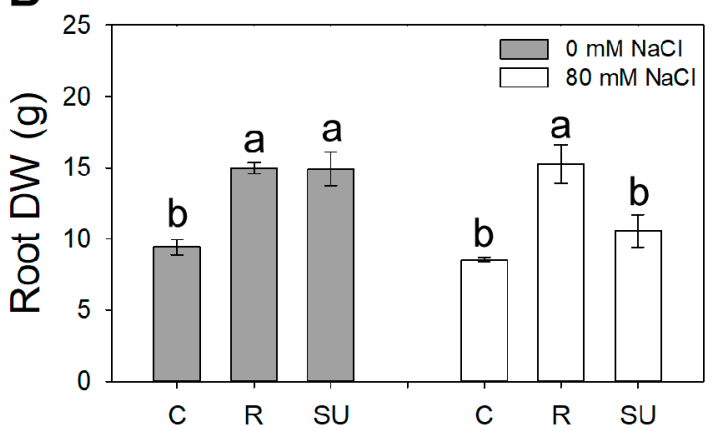

Figure 1. (A) Leaf area and (B) root DW in control plants (C) and plants treated with Rygex (R) and Super Fifty (SU) and subjected to $0 \mathrm{mM} \mathrm{NaCl}$ (grey bars) and $80 \mathrm{mM} \mathrm{NaCl}$ (white bars). Different letters indicate significant differences according to Duncan post-hoc test $(p<0.05)$. 


\subsection{Leaf Gas Exchanges}

Biostimulant treatments induced higher net photosynthesis compared to untreated plants, with $27 \%$ and 31\% increase for Rygex and Super Fifty, respectively (Table 2). In contrast, salinity caused a significant reduction in net photosynthesis $(-18 \%)$. Similarly, the stomatal conductance was only affected by the single effect of salinity, with a $27 \%$ reduction compared to non-salinized control plants (Table 2). No significant interaction between biostimulant treatment and salinity was observed for net photosynthesis and stomatal conductance.

Table 2. Net photosynthesis (Pn), stomatal conductance (gs), leaf water potential ( $\left.\Psi_{\text {leaf }}\right)$ and intrinsic water use efficiency (iWUE) in control plants and plants treated with Rygex and Super Fifty and subjected to $0 \mathrm{mM} \mathrm{NaCl}$ (S0) and $80 \mathrm{mM} \mathrm{NaCl}$ (S80). Asterisks indicate significant differences according to ANOVA (ns = not significant; ${ }^{*}=p<0.05 ;{ }^{* *}=p<0.01 ;{ }^{* * *}=p<0.001$ ). For statistically significant differences induced by one of the two factors, different letters indicate significant differences according to Duncan post-hoc test $(p<0.05)$.

\begin{tabular}{|c|c|c|c|c|}
\hline & Pn & gs & $\Psi_{\text {leaf }}$ & iWUE \\
\hline & $\mu \mathrm{mol} \mathrm{m} \mathrm{m}^{-2} \mathrm{~s}^{-1}$ & $\mathrm{mmol} \mathrm{m}^{-2}$ & $\mathrm{MPa}$ & \\
\hline \multicolumn{5}{|l|}{ Biostimulant (B) } \\
\hline Control & $6.68 \mathrm{~b}$ & 109.7 & -1.32 & 0.071 \\
\hline Rygex & $8.56 \mathrm{a}$ & 108.4 & -1.51 & 0.081 \\
\hline Super Fifty & $8.76 \mathrm{a}$ & 104.7 & -1.53 & 0.084 \\
\hline \multicolumn{5}{|l|}{ Salinity (S) } \\
\hline so & $8.81 \mathrm{a}$ & $124.8 \mathrm{a}$ & $-1.21 \mathrm{a}$ & 0.074 \\
\hline S80 & $7.17 \mathrm{~b}$ & $91.52 \mathrm{~b}$ & $-1.69 b$ & 0.082 \\
\hline \multicolumn{5}{|l|}{ Significance } \\
\hline B & $* *$ & ns & ns & ns \\
\hline$S$ & $* *$ & $*$ & $* * *$ & ns \\
\hline $\mathrm{BxS}$ & ns & ns & * & * \\
\hline
\end{tabular}

A significant interaction between biostimulants and salinity was found for the intrinsic water use efficiency (iWUE) (Table 2), with significant increases in plants treated with the two SWE under control conditions, while no difference was found when grown under salinity (Figure 2).

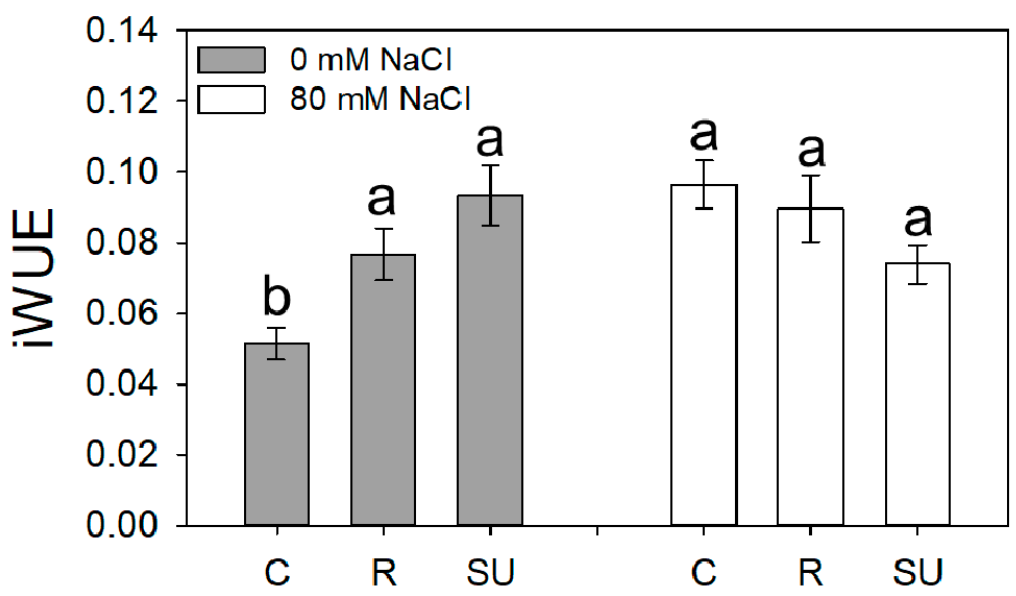

Figure 2. Intrinsic water use efficiency (iWUE) in plants treated with Rygex (R) and Super Fifty (SU) and subjected to $0 \mathrm{mM} \mathrm{NaCl}$ (grey bars) and $80 \mathrm{mM} \mathrm{NaCl}$ (white bars). Different letters indicate significant differences according to Duncan post-hoc test $(p<0.05)$.

The results on leaf water potential showed a significant interaction between biostimulant treatment and salinity (Table 2). In non-salinized plots, the leaf water potential was remarkably lower in plants 
treated with both Rygex (-64\%) and Super Fifty $(-76 \%)$ vs. untreated control plants. In contrast, under salt stress, the leaf water potential was similar in SWE-treated and untreated plants. Nevertheless, salinity caused a 2.2-fold decrease in leaf water potential in control plants, whereas the difference was not significant in SWE-treated plants (Figure 3).

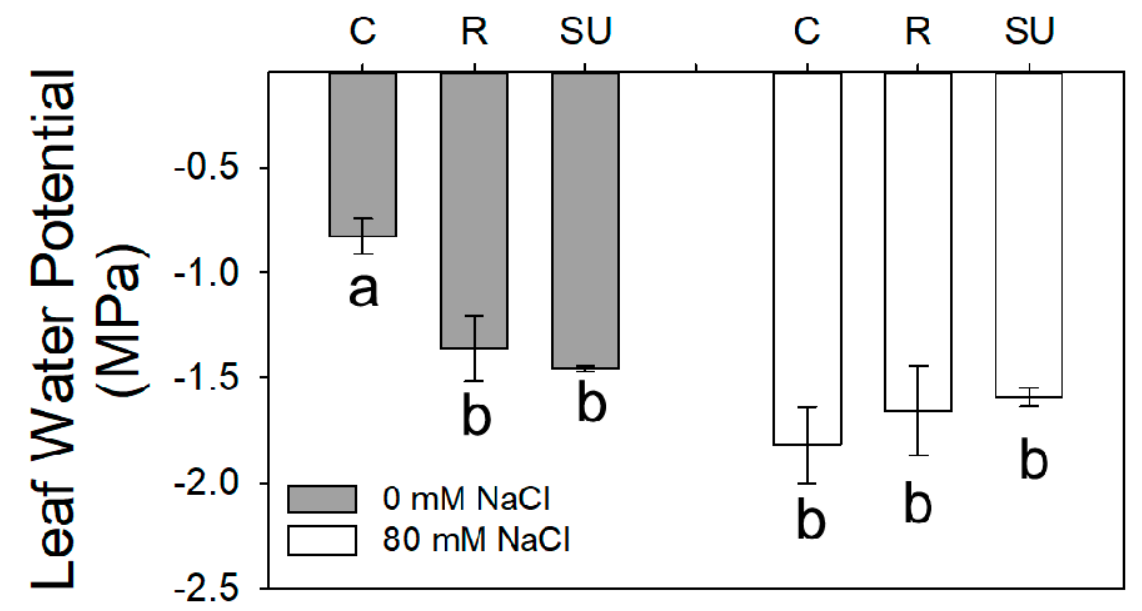

Figure 3. Leaf water potential in plants treated with Rygex (R) and Super Fifty (SU) and subjected to $0 \mathrm{mM} \mathrm{NaCl}$ (grey bars) and $80 \mathrm{mM} \mathrm{NaCl}$ (white bars). Different letters indicate significant differences according to Duncan post-hoc test $(p<0.05)$.

\subsection{Leaf and Fruit Ions Content}

$\mathrm{Na}^{+}$leaf content was only affected by salinity (10-fold increase), while no effect of the biostimulant treatments or the interaction between the two factors was observed. Both SWE treatments induced a $48 \%$ reduction in $\mathrm{NO}_{3}{ }^{-}$leaf concentration. In contrast, salinity induced higher concentration of $\mathrm{NO}_{3}{ }^{-}-$ in leaf tissues (2.4-fold increase). The fruit concentrations of $\mathrm{K}^{+}, \mathrm{Ca}^{2+}$ and $\mathrm{Mg}^{2+}$ were significantly affected only by biostimulant treatments, while no significant differences were associated with salinity nor by the interaction between salinity and SWE treatments. $\mathrm{K}^{+}, \mathrm{Ca}^{2+}$ and $\mathrm{Mg}^{2+}$ fruit concentration was significantly reduced by Rygex $(-20 \%,-35 \%$ and $-23 \%)$ as well as by Super Fifty $(-15 \%,-28 \%$ and $-14 \%$ ) (Table 3).

Table 3. Leaf and fruit ions content in control plants (C) and plants treated with Rygex (R) and Super Fifty (SU) and subjected to $0 \mathrm{mM} \mathrm{NaCl}$ (S0) and $80 \mathrm{mM} \mathrm{NaCl}$ (S80). Asterisks indicate significant differences according to ANOVA (ns = not significant; ${ }^{*}=p<0.05 ;{ }^{* *}=p<0.01$; ${ }^{* * *}=p<0.001$ ). For statistically significant differences induced by one of the two factors, different letters indicate significant differences according to Duncan post-hoc test $(p<0.05)$.

\begin{tabular}{|c|c|c|c|c|c|c|}
\hline & \multicolumn{3}{|c|}{ Leaf } & \multicolumn{3}{|c|}{ Fruit } \\
\hline & $\mathrm{Na}^{+}$ & $\mathrm{NO}_{3}{ }^{-}$ & $\mathrm{K}^{+}$ & $\mathrm{K}^{+}$ & $\mathrm{Ca}^{2+}$ & $\mathrm{Mg}^{2+}$ \\
\hline & $\mathrm{g} \mathrm{kg}^{-1} \mathrm{DW}$ & $\mathrm{g} \mathrm{kg}^{-1} \mathrm{DW}$ & $\mathrm{g} \mathrm{kg}^{-1} \mathrm{DW}$ & $\mathrm{g} \mathrm{kg}^{-1} \mathrm{DW}$ & $\mathrm{g} \mathrm{kg}^{-1} \mathrm{DW}$ & $\mathrm{g} \mathrm{kg}^{-1} \mathrm{DW}$ \\
\hline \multicolumn{7}{|l|}{ Biostimulant (B) } \\
\hline Control & 2.67 & $3.72 \mathrm{a}$ & $22.9 \mathrm{a}$ & $36.1 \mathrm{a}$ & $0.46 \mathrm{a}$ & $1.49 \mathrm{a}$ \\
\hline Rygex & 2.78 & $1.94 \mathrm{~b}$ & $20.1 \mathrm{a}$ & $28.9 \mathrm{~b}$ & $0.30 \mathrm{~b}$ & $1.15 \mathrm{~b}$ \\
\hline Super Fifty & 2.16 & $1.95 \mathrm{~b}$ & $17.6 \mathrm{~b}$ & $30.7 \mathrm{~b}$ & $0.33 \mathrm{~b}$ & $1.29 \mathrm{~b}$ \\
\hline \multicolumn{7}{|l|}{ Salinity (S) } \\
\hline So & $0.43 \mathrm{~b}$ & $1.49 \mathrm{~b}$ & $23.20 \mathrm{a}$ & 31.78 & 0.35 & 1.32 \\
\hline $\mathrm{S} 80$ & $4.31 \mathrm{a}$ & $3.59 \mathrm{a}$ & $17.24 \mathrm{~b}$ & 32.02 & 0.38 & 1.29 \\
\hline \multicolumn{7}{|l|}{ Significance } \\
\hline B & $\mathrm{ns}$ & * & * & * & * & * \\
\hline $\mathrm{S}$ & $* * *$ & $* *$ & $* * *$ & ns & $\mathrm{ns}$ & $\mathrm{ns}$ \\
\hline BxS & ns & ns & * & ns & ns & ns \\
\hline
\end{tabular}


The concentration of $\mathrm{K}^{+}$in leaves was significantly affected by the interaction between biostimulant and salinity (Table 3). Both Rygex and Super Fifty reduced $\mathrm{K}^{+}$leaf concentration vs. control plants $(-24 \%$ and $-33 \%$, respectively), whereas no differences were found under salinity (Figure 4$)$.

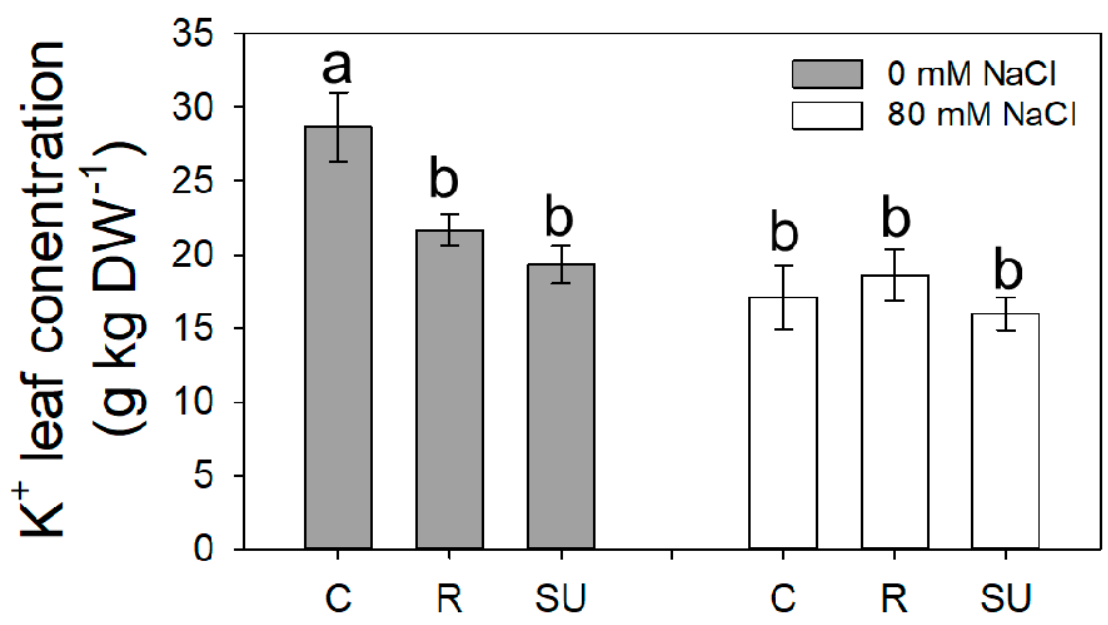

Figure 4. Potassium $\left(\mathrm{K}^{+}\right)$leaf concentration in control plants $(\mathrm{C})$ and plants treated with Rygex (R) and Super Fifty (SU) and subjected to $0 \mathrm{mM} \mathrm{NaCl}$ (grey bars) and $80 \mathrm{mM} \mathrm{NaCl}$ (white bars). Different letters indicate significant differences according to Duncan post-hoc test $(p<0.05)$.

\subsection{Yield Components}

Plants treated with SWE showed a general yield increase. Specifically, the yield increase due to biostimulant treatments was $+49 \%$ with Rygex and $+70 \%$ with Super Fifty (Table 4 ). As expected, salinity caused significant yield losses $(-33 \%)$. The Harvest Index, which indicates the amount of dry biomass allocated in fruits on the total plant dry biomass [32], was enhanced by biostimulant treatments, with $+10 \%$ and $+12 \%$ higher values for Rygex and Super Fifty, respectively (Table 4 ). This parameter was not significantly affected by salinity (Table 4). Both yield and Harvest Index were not significantly affected by the interaction between biostimulant and salinity (Table 4). Finally, fruit firmness from SWE-treated plants was lower compared to control fruits (Table 4). This parameter was only evaluated under control conditions.

Table 4. Yield components in control plants and plants treated with Rygex (R) and Super Fifty (SU) and subjected to $0 \mathrm{mM} \mathrm{NaCl}$ (S0) and $80 \mathrm{mM} \mathrm{NaCl}$ (S80). Asterisks indicate significant differences according to ANOVA ( $\mathrm{ns}=$ not significant; ${ }^{* *}=p<0.01{ }^{* * *}=p<0.001$ ). For statistically significant differences induced by one of the two factors, different letters indicate significant differences according to Duncan post-hoc test $(p<0.05)$.

\begin{tabular}{|c|c|c|c|c|c|}
\hline & FruitsFW & HarvestIndex & Firmness & Average FruitFW & Numberof Fruits \\
\hline & (g) & & $\left(\mathrm{kg} \mathrm{cm}^{-1}\right)$ & (g fruit ${ }^{-1}$ ) & (\#) \\
\hline \multicolumn{6}{|c|}{ Biostimulant (B) } \\
\hline Control & $486.1 \mathrm{~b}$ & $0.25 \mathrm{~b}$ & $1.49 \mathrm{a}$ & $10.01 \mathrm{~b}$ & 51.5 \\
\hline Rygex & $722.8 \mathrm{a}$ & $0.35 \mathrm{a}$ & $0.91 \mathrm{~b}$ & $12.52 \mathrm{a}$ & 58.2 \\
\hline Super Fifty & 826.7 a & $0.37 \mathrm{a}$ & $0.52 c$ & $13.47 \mathrm{a}$ & 61.3 \\
\hline \multicolumn{6}{|l|}{ Salinity (S) } \\
\hline so & 828.9 a & 0.52 & - & 12.64 & $65.8 \mathrm{a}$ \\
\hline S80 & $528.3 \mathrm{~b}$ & 0.48 & - & 11.37 & $48.3 \mathrm{~b}$ \\
\hline \multicolumn{6}{|l|}{ Significance } \\
\hline B & $* * *$ & $* *$ & $* * *$ & $* * *$ & ns \\
\hline$S$ & $* * *$ & ns & - & ns & $* * *$ \\
\hline $\mathrm{BxS}$ & ns & ns & - & $* * *$ & $* * *$ \\
\hline
\end{tabular}


The average fruit weight and the number of fruits per plant were both significantly affected by the interaction biostimulant $x$ salinity (Table 4). The biostimulant treatments did not induce any change in average fruit weight under optimal conditions (Figure 5A). However, both SWE increased by $85 \%$ and $96 \%$ the average fruit fresh weight under salinity when compared with the control in Rygex- and Super-Fifty-treated plants, respectively (Figure 5A). On the contrary, the number of fruits was higher in plants treated with Rygex $(+45 \%)$ and Super Fifty $(+64 \%)$ compared to control plants, while under salinity stress this parameter was not affected by SWE treatments (Figure 5B).

A

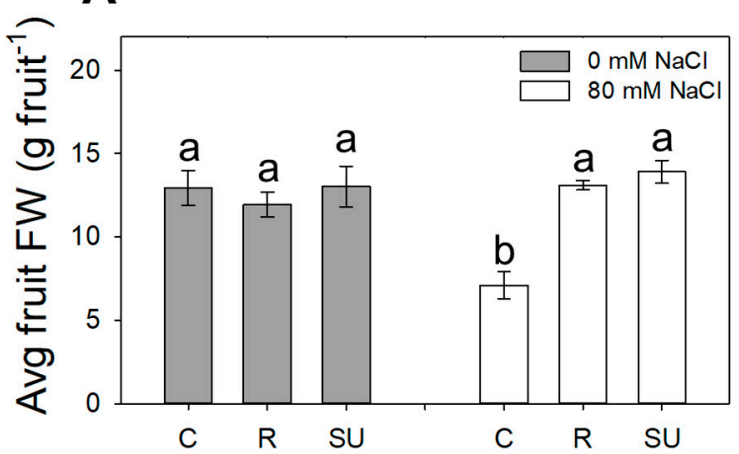

B

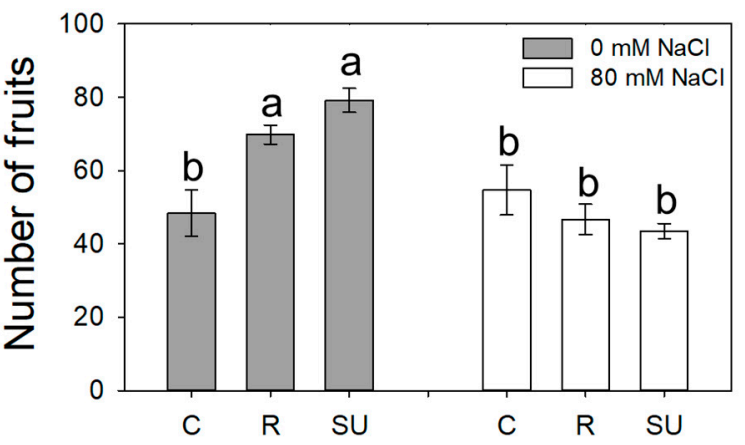

Figure 5. (A) Average fruit fresh weight and (B) number of fruit weight in control plants (C) and plants treated with Rygex (R) and Super Fifty (SU) and subjected to $0 \mathrm{mM} \mathrm{NaCl}$ (grey bars) and $80 \mathrm{mM}$ $\mathrm{NaCl}$ (white bars). Different letters indicate significant differences according to Duncan post-hoc test $(p<0.05)$.

\section{Discussion}

\subsection{Biostimulants Determine Stress Preadaptation}

Salinity is an ever-expanding abiotic stress that impacts crop yield and endangers human food supply [33]. Coping with salinization is therefore increasingly important to counteract agricultural productions in the face of climate change [5]. Biostimulants have been proved to reduce yield loss in response to abiotic stresses [9]. However, the general multi-molecular nature of commercial biostimulants greatly limits a complete understanding of their mechanism of action, which is essential to improve their function and better match their applications vs. agricultural needs [14]. The mode of action of SWE has been correlated with high concentrations of beneficial molecules such as auxin-like molecules, proline, mannitol, and several essential amino acids that have been proven to potentiate stress related mechanisms, including osmo-protection $[13,20]$. Rygex and Super Fifty have been previously characterized [13,30], and their formulations present a high content of different osmolytes, mainly amino acids for Rygex, and mannitol and sorbitol for Super Fifty (Figure S1). Moreover, both biostimulants have relatively high ion contents, including $\mathrm{Na}^{+}$and $\mathrm{Cl}^{-}$, and high amount of $\mathrm{Ca}^{2+}$ and $\mathrm{Mg}^{2+}$ for the Rygex and $\mathrm{Ca}^{2+}$ and $\mathrm{K}^{+}$for Super Fifty, which are all possibly associated with the natural habitat of seaweeds [13]. The high concentration of osmotically active molecules and ions in SWE-treated plants was consistent with an effect on their leaf water potential which was significantly reduced (Figure 3). The reduction in leaf water potentials may have been caused by a moderate osmotic stress due to root-zone localized SWE treatments [14], uptake of osmo-active molecules that may have simulated a stress response [34,35], activation of stress signaling via sensing of stress molecules or combinations of these events at root level [26,33]. A decrease in leaf water potential is indeed a common response to osmotic stress, a shared component of various abiotic stresses including salinity, drought, and high light [36]. Similarly, physiological production or uptake of osmolytes has been correlated with plants ability to survive severe drought [37]. Most likely, in plants treated with SWE, the continuous application of a concentrated mix of osmotically active molecules during plant growth could have induced a moderate yet continuous osmotic stress that triggered a reshape of plant 
morphology both at leaf as well as whole plant level. The presence of macronutrients in SWE may have also contributed to the overall plant growth. However, the amounts of nutrients provided by SWE applications were very low and unlikely to affect the plant nutritional state, as previously demonstrated by Sharma et al. 2016 [30] and were further confirmed by our results on biomass accumulation and ion content in SWE-treated plants (Tables 1-3).

\subsection{Biomass Redistribution Facilitates Stress Adaptation}

SWE application determined a higher allocation of biomass to roots compared to shoot, as indicated by the higher root to shoot ratio (R/S) in both Rygex and Super Fifty treated plants (Table 1). The beneficial effect of Rygex on root growth was reported in Vigna radiata hypocotyls and was correlated with the presence of auxin-like molecules in its formulation [30]. Moreover, plants subjected to drought and salinity generally show higher root to shoot ratios [38,39]. This adaptation mechanism appears to be functional and necessary to increase plant ability to absorb water and reduce transpiration under water limited conditions [38]. Therefore, the high concentration of soluble sugars (in Super Fifty) and amino acids (in Rygex) may have functionally altered to R/S and consequently protected plants by a seasonal salt build-up in the rootzone (Table 1). Biomass reallocation represents an important plasticity trait in plant response to environmental stresses $[38,40]$ because of specific functionalities and metabolic costs of different plant tissues and organs. Indeed, in order to maximize chances for growth and survival, plants must optimize their biomass allocation depending on the specific surrounding environment [39]. Although both SWEs induced similar responses in terms of R/S modifications (Table 1), the two SWEs induced different responses on root biomass accumulation under salinity (Table 1, Figure 1B). Rygex treatments determined higher root growth both under control and salt stress conditions, whereas Super Fifty did not elicit the same response under stress (Figure 1B). Although the two commercial products had different compositions [13], these results highlight the molecular complexity of biostimulant products, which may limit/hinder our understanding of the functional links and/or cause/effect responses in the interaction of plant/biostimulant [14]. In addition, such complexity requires a systematic mapping of biostimulant compositions vs. applications [20]. Both SWEs induced a lower shoot biomass accumulation (Table 1 ) and leaf expansion (Figure 1A), with a stronger effect in Super Fifty vs. Rygex. High concentrations of mannitol and sorbitol in Super Fifty [13], which have been shown to have positive effects when overproduced in plants exposed to drought and/or salinity may have induced an osmo-priming and/or pre-functionalization of adaptation mechanisms [34,35]. Pre-adaptation was correlated with a general higher $\mathrm{CO}_{2}$ assimilation rates in SWE-treated plants, without significant differences regarding stomatal conductance (Table 2), indicating that SWE may have morphologically adapted plants to cope with an unfavorable water potential gradient due to seasonal salinization, which may have in turn protected the photosynthetic system [41]. As a consequence, SWE applications increased plant water use efficiency (Figure 2), having higher $\mathrm{CO}_{2}$ assimilation rates per unit of water loss.

\subsection{Plant Biostimulants Mediate Nutrient Use Efficiency}

Ion uptake is also largely affected under salt stress and it plays at the same time an important role in adaptation [42,43]. Plants treated with SWE had lower ions contents in their tissues, with respect to $\mathrm{NO}_{3}{ }^{-}$and $\mathrm{K}^{+}$in the leaves, and $\mathrm{K}^{+}, \mathrm{Ca}^{2+}$ and $\mathrm{Mg}^{2+}$ in the fruits (Table 3). Considering that SWE-treated plants had similar or higher yield than control plants, our results indicate that SWE improved plant nutrient use efficiency. This could have been likely a consequence of a reduced shoot biomass and overall rearrangement of the biomass partitioning [44-46]. Additionally, these results suggest that the lower water potential of SWE-treated plants was not due to ion accumulation, but to the accumulation of other osmolytes that were functional for plants adaptation to a hyperosmotic environment [47]. Higher water and nutrient use efficiency of SWE-treated plants have probably been the main effectors determining higher productivity under both control and salt stress conditions, with marginal differences between the two biostimulants. Under control conditions, the higher productivity of tomato plants 
treated with SWE seemed to be linked with an enhanced fruit setting, as indicated by the higher number of fruits (Table 4), without an effect on their average weight (Figure 5). The beneficial action of SWE on tomato productivity was displayed both under control and salt stress conditions, with a higher proportion of biomass allocated to fruits than photosynthetic organs compared to untreated plants (Table 4). Improving the Harvest Index [32] is highly valuable in resource-limited agricultural contexts to maximize crop resource use efficiency and productivity through a reduced allocation of biomass in not edible plants portions [32]. Moreover, an early shift from a vegetative to a reproductive stage is typically associated with osmotic stress as an evolutionary heritage allowing plants to complete their growth cycle in a faster way to escape upcoming unfavorable conditions. These may include drought events in natural environments but also seasonal salinization in agricultural contexts [48,49]. Although flowering time between SWE-treated vs. control plants was not measured in our experimental set-up, at-harvest fruits from SWE-treated plants were at an advanced state of ripening compared to controls, as indicated by their significantly lower firmness (Table 4). An early flowering and fruit onset could be beneficial when crops are irrigated with saline water, since highly sensitive phenological stages would anticipate the accumulation of salts in the root zone due to saline irrigation [49]. In summer crops of Mediterranean environments, irrigation with brackish water causes a build-up of salt in the soil which normally reaches a critical crop tolerance threshold at the end of the growth cycle [49]. It is possible that early flowering and fruit onset observed in SWE-treated plants were part of the osmo-priming program activated by Rygex and Super Fifty. This in turn determined an increased tomato yield, both under control and salt stress conditions.

\section{Conclusions}

Overall, these results provide evidence for a SWE-mediated osmo-priming of tomato plants that has led to stress protection in response to salinity. SWE-based biostimulants can be useful to preserve yield loss in areas where hot temperatures and water shortage force farmers to use poor quality waters (brackish or saline). These results also shed light on the mechanisms of action of biostimulants in real agricultural contexts and provide the scientific basis for designing new commercial products that may be more effective in a developing climate-smart agriculture.

Supplementary Materials: The following are available online at http://www.mdpi.com/2073-4395/10/10/1559/s1, Figure S1: Rygex and Super Fifty composition from Di Stasio et al., 2018. Within each variable different letters indicate significant differences. Vertical bars indicate \pm SE of means.

Author Contributions: Conceptualization, E.D.S., G.R. and A.M.; data curation, E.D.S. and A.M.; formal analysis, V.C.; funding acquisition, A.M.; investigation, E.D.S., G.R. and M.G.; visualization, V.C.; writing-original draft, E.D.S., V.C., M.E. and A.M.; writing-review and editing, V.C. and A.M. All authors have read and agreed to the published version of the manuscript.

Funding: This research was funded by the EU Project BIOFECTOR Plant Growth-Promoting Bio-Effectors (\#FP7KBBE-2012-6 Grant Agreement 312117).

Conflicts of Interest: The authors declare no conflict of interest.

\section{References}

1. Shrivastava, P.; Kumar, R. Soil salinity: A serious environmental issue and plant growth promoting bacteria as one of the tools for its alleviation. Saudi J. Biol. Sci. 2015, 22, 123-131. [CrossRef] [PubMed]

2. Libutti, A.; Monteleone, M. Irrigation management in Mediterranean salt affected agriculture: How leaching operates. Ital. J. Agron. 2012, 7, 5. [CrossRef]

3. Hasegawa, P.; Bressan, R.; Zhu, J.; Bohnert, H. Plant cellular and molecular response to high salinity. Annu. Rev. Plant Biol. 2000, 51, 463-499. [CrossRef] [PubMed]

4. Mondal, M.K.; Bhuiyan, S.I.; Franco, D.T. Soil salinity reduction and prediction of salt dynamics in the coastal ricelands of Bangladesh. Agric. Water Manag. 2001, 47, 9-23. [CrossRef]

5. Machado, R.M.A.; Serralheiro, R.P. Soil salinity: Effect on vegetable crop growth. Management practices to prevent and mitigate soil salinization. Horticulturae 2017, 3, 30. [CrossRef] 
6. Munns, R.; Tester, M. Mechanisms of Salinity Tolerance. Annu. Rev. Plant Biol. 2008, 59, 651-681. [CrossRef]

7. Wani, S.H.; Kumar, V.; Khare, T.; Guddimalli, R.; Parveda, M.; Solymosi, K.; Suprasanna, P.; Kavi Kishor, P.B. Engineering salinity tolerance in plants: Progress and prospects. Planta 2020, 251, 1-29. [CrossRef]

8. Parađiković, N.; Teklić, T.; Zeljković, S.; Lisjak, M.; Špoljarević, M. Biostimulants research in some horticultural plant species-A review. Food Energy Secur. 2019, 8, e00162. [CrossRef]

9. Calvo, P.; Nelson, L.; Kloepper, J.W. Agricultural uses of plant biostimulants. Plant Soil 2014, 383, 3-41. [CrossRef]

10. Plaut, Z.; Edelstein, M.; Ben-Hur, M. Overcoming Salinity Barriers to Crop Production Using Traditional Methods. CRC Crit. Rev. Plant Sci. 2013, 32, 250-291. [CrossRef]

11. du Jardin, P. Plant biostimulants: Definition, concept, main categories and regulation. Sci. Hortic. 2015, 196, 3-14. [CrossRef]

12. Van Oosten, M.J.; Pepe, O.; De Pascale, S.; Silletti, S.; Maggio, A. The role of biostimulants and bioeffectors as alleviators of abiotic stress in crop plants. Chem. Biol. Technol. Agric. 2017, 4, 5. [CrossRef]

13. Di Stasio, E.; Van Oosten, M.J.; Silletti, S.; Raimondi, G.; dell'Aversana, E.; Carillo, P.; Maggio, A. Ascophyllum nodosum-based algal extracts act as enhancers of growth, fruit quality, and adaptation to stress in salinized tomato plants. J. Appl. Phycol. 2018, 30, 2675-2686. [CrossRef]

14. El Boukhari, M.E.M.; Barakate, M.; Bouhia, Y.; Lyamlouli, K. Trends in seaweed extract based biostimulants: Manufacturing process and beneficial effect on soil-plant systems. Plants 2020, 9, 359. [CrossRef] [PubMed]

15. Mattner, S.W.; Wite, D.; Riches, D.A.; Porter, I.J.; Arioli, T. The effect of kelp extract on seedling establishment of broccoli on contrasting soil types in southern Victoria, Australia. Biol. Agric. Hortic. 2013, 29, 258-270. [CrossRef]

16. Elansary, H.O.; Skalicka-Woźniak, K.; King, I.W. Enhancing stress growth traits as well as phytochemical and antioxidant contents of Spiraea and Pittosporum under seaweed extract treatments. Plant Physiol. Biochem. 2016, 105, 310-320. [CrossRef]

17. $\mathrm{Xu}, \mathrm{C}$.; Leskovar, D.I. Effects of $A$. nodosum seaweed extracts on spinach growth, physiology and nutrition value under drought stress. Sci. Hortic. 2015, 183, 39-47. [CrossRef]

18. Papenfus, H.B.; Kulkarni, M.G.; Stirk, W.A.; Finnie, J.F.; Van Staden, J. Effect of a commercial seaweed extract $\left(\operatorname{Kelpak}^{\circledR}\right)$ and polyamines on nutrient-deprived (N, P and K) okra seedlings. Sci. Hortic. 2013, 151, 142-146. [CrossRef]

19. Halpern, M.; Bar-Tal, A.; Ofek, M.; Minz, D.; Muller, T.; Yermiyahu, U. The Use of Biostimulants for Enhancing Nutrient Uptake. Adv. Agron. 2015, 130, 141-174.

20. Fleming, T.R.; Fleming, C.C.; Levy, C.C.B.; Repiso, C.; Hennequart, F.; Nolasco, J.B.; Liu, F. Biostimulants enhance growth and drought tolerance in Arabidopsis thaliana and exhibit chemical priming action. Ann. Appl. Biol. 2019, 174, 153-165. [CrossRef]

21. Kawatra, M.; Kaur, K.; Kaur, G. Effect of osmo priming on sucrose metabolism in spring maize, during the period of grain filling, under limited irrigation conditions. Physiol. Mol. Biol. Plants 2019, 25, 1367-1376. [CrossRef] [PubMed]

22. Bourioug, M.; Ezzaza, K.; Bouabid, R.; Alaoui-Mhamdi, M.; Bungau, S.; Bourgeade, P.; Alaoui-Sossé, L.; Alaoui-Sossé, B.; Aleya, L. Influence of hydro- and osmo-priming on sunflower seeds to break dormancy and improve crop performance under water stress. Environ. Sci. Pollut. Res. 2020, 1-12. [CrossRef] [PubMed]

23. Hakeem, A.; Liu, Y.; Zhang, L.; Si, T.; Jiang, D. Induction of osmotic stress resistance by seed osmo-priming in winter wheat (Triticum aestivum L.) during post-germinative stages. Seed Sci. Technol. 2017, 45, 485-498. [CrossRef]

24. Lemmens, E.; Deleu, L.J.; De Brier, N.; De Man, W.L.; De Proft, M.; Prinsen, E.; Delcour, J.A. The Impact of Hydro-Priming and Osmo-Priming on Seedling Characteristics, Plant Hormone Concentrations, Activity of Selected Hydrolytic Enzymes, and Cell Wall and Phytate Hydrolysis in Sprouted Wheat (Triticum aestivum L.). ACS Omega 2019, 4, 22089-22100. [CrossRef] [PubMed]

25. Tabassum, T.; Farooq, M.; Ahmad, R.; Zohaib, A.; Wahid, A. Seed priming and transgenerational drought memory improves tolerance against salt stress in bread wheat. Plant Physiol. Biochem. 2017, 118, 362-369. [CrossRef] [PubMed]

26. Kerchev, P.; van der Meer, T.; Sujeeth, N.; Verlee, A.; Stevens, C.V.; Van Breusegem, F.; Gechev, T. Molecular priming as an approach to induce tolerance against abiotic and oxidative stresses in crop plants. Biotechnol. Adv. 2020, 40, 107503. [CrossRef] [PubMed] 
27. Mouradi, M.; Bouizgaren, A.; Farissi, M.; Latrach, L.; Qaddoury, A.; Ghoulam, C. Seed osmopriming improves plant growth, nodulation, chlorophyll fluorescence and nutrient uptake in alfalfa (Medicago sativa L.)-rhizobia symbiosis under drought stress. Sci. Hortic. 2016, 213, 232-242. [CrossRef]

28. Pawar, V.A.; Laware, S.L. Seed Priming A Critical Review. Int. J. Sci. Res. Biol. Sci. 2018, 5, 94-101. [CrossRef]

29. Abebe, S.N. Effect of hydro and osmo priming on yield and yield components of Chickpea (Cicer arietinum L.). Afr. J. Agric. Res. 2016, 11, 3027-3036. [CrossRef]

30. Sharma, H.S.S.; Selby, C.; Carmichael, E.; McRoberts, C.; Rao, J.R.; Ambrosino, P.; Chiurazzi, M.; Pucci, M.; Martin, T. Physicochemical analyses of plant biostimulant formulations and characterisation of commercial products by instrumental techniques. Chem. Biol. Technol. Agric. 2016, 3, 13. [CrossRef]

31. Muthu-Pandian Chanthini, K.; Senthil-Nathan, S.; Stanley-Raja, V.; Thanigaivel, A.; Karthi, S.; Sivanesh, H.; Sundar, N.S.; Palanikani, R.; Soranam, R. Chaetomorpha antennina (Bory) Kützing derived seaweed liquid fertilizers as prospective bio-stimulant for Lycopersicon esculentum (Mill). Biocatal. Agric. Biotechnol. 2019, 20, 101190. [CrossRef]

32. Buchanan, B.B.; Gruissem, W.; Jones, R.L. Biochemistry and Molecular Biology of Plants, 2nd ed.; John Wiley \& Sons, Ltd.: Chichester, UK, 2015.

33. Yang, Y.; Guo, Y. Unraveling salt stress signaling in plants. J. Integr. Plant Biol. 2018, 60, 796-804. [CrossRef] [PubMed]

34. Zouari, M.; Hassena, A.; Trabelsi, L.; Rouina, B.; Decou, R.; Labrousse, P. Exogenous Proline-Mediated Abiotic Stress Tolerance in Plants: Possible Mechanisms. In Osmoprotectant-Mediated Abiotic Stress Tolerance in Plants; Springer Nature: Cham, Switzerland, 2019.

35. Gholami Zali, A.; Ehsanzadeh, P. Exogenous proline improves osmoregulation, physiological functions, essential oil, and seed yield of fennel. Ind. Crops Prod. 2018, 111, 133-140. [CrossRef]

36. Haswell, E.S.; Verslues, P.E. The ongoing search for the molecular basis of plant osmosensing. J. Gen. Physiol. 2015, 145, 389-394. [CrossRef] [PubMed]

37. Liu, F.; Stützel, H. Biomass partitioning, specific leaf area, and water use efficiency of vegetable amaranth (Amaranthus spp.) in response to drought stress. Sci. Hortic. 2004, 102, 15-27. [CrossRef]

38. Xu, W.; Cui, K.; Xu, A.; Nie, L.; Huang, J.; Peng, S. Drought stress condition increases root to shoot ratio via alteration of carbohydrate partitioning and enzymatic activity in rice seedlings. Acta Physiol. Plant. 2015, 37, 9. [CrossRef]

39. Eziz, A.; Yan, Z.; Tian, D.; Han, W.; Tang, Z.; Fang, J. Drought effect on plant biomass allocation: A meta-analysis. Ecol. Evol. 2017, 7, 11002-11010. [CrossRef] [PubMed]

40. Roycewicz, P.; Malamy, J.E. Dissecting the effects of nitrate, sucrose and osmotic potential on Arabidopsis root and shoot system growth in laboratory assays. Philos. Trans. R. Soc. B Biol. Sci. 2012, 367, 1489-1500. [CrossRef]

41. Condon, A.G. Drying times: Plant traits to improve crop water use efficiency and yield. J. Exp. Bot. 2020, 71, 2239-2252. [CrossRef]

42. Wang, H.; Zhang, M.; Guo, R.; Shi, D.; Liu, B.; Lin, X.; Yang, C. Effects of salt stress on ion balance and nitrogen metabolism of old and young leaves in rice (Oryza sativa L.). BMC Plant Biol. 2012, 12, 194. [CrossRef]

43. Guo, H.; Li, S.; Min, W.; Ye, J.; Hou, Z. Ionomic and transcriptomic analyses of two cotton cultivars (Gossypium hirsutum L.) provide insights into the ion balance mechanism of cotton under salt stress. PLoS ONE 2019, 14, e0226776. [CrossRef] [PubMed]

44. Lorenzen, B.; Brix, H.; Mendelssohn, I.A.; McKee, K.L.; Miao, S.L. Growth, biomass allocation and nutrient use efficiency in Cladium jamaicense and Typha domingensis as affected by phosphorus and oxygen availability. Aquat. Bot. 2001, 70, 117-133. [CrossRef]

45. Duncan, E.G.; O'Sullivan, C.A.; Roper, M.M.; Palta, J.; Whisson, K.; Peoples, M.B. Yield and nitrogen use efficiency of wheat increased with root length and biomass due to nitrogen, phosphorus, and potassium interactions. J. Plant Nutr. Soil Sci. 2018, 181, 364-373. [CrossRef]

46. Chen, L.; Liao, H. Engineering crop nutrient efficiency for sustainable agriculture. J. Integr. Plant Biol. 2017, 59, 710-735. [CrossRef] [PubMed]

47. Wang, X.; Mao, Z.; Zhang, J.; Hemat, M.; Huang, M.; Cai, J.; Zhou, Q.; Dai, T.; Jiang, D. Osmolyte accumulation plays important roles in the drought priming induced tolerance to post-anthesis drought stress in winter wheat (Triticum aestivum L.). Environ. Exp. Bot. 2019, 166, 103804. [CrossRef] 
48. Cirillo, V.; Masin, R.; Maggio, A.; Zanin, G. Crop-weed interactions in saline environments. Eur. J. Agron. 2018, 99, 51-61. [CrossRef]

49. De Pascale, S.; Orsini, F.; Caputo, R.; Palermo, M.A.; Barbieri, G.; Maggio, A. Seasonal and multiannual effects of salinisation on tomato yield and fruit quality. Funct. Plant Biol. 2012, 39, 689-698. [CrossRef]

(C) 2020 by the authors. Licensee MDPI, Basel, Switzerland. This article is an open access article distributed under the terms and conditions of the Creative Commons Attribution (CC BY) license (http://creativecommons.org/licenses/by/4.0/). 